\title{
Microbial Composition in Cadmium Contaminated Soils around Zinc Mining Area, Thailand
}

\author{
Uratchwee Unhalekhaka (Corresponding author) \\ Environmental Science (Interdisciplinary program) \\ Graduate School, Chulalongkorn University \\ Phyathai Road, Pathumwan, Bangkok, Thailand 10330 \\ Tel: 66-2-218-7666 E-mail: aummiee@yahoo.com \\ Charnwit Kositanont \\ Department of Microbiology, Faculty of Science, Chulalongkorn University \\ Phyathai Road, Pathumwan, Bangkok, Thailand 10330 \\ Tel: 66-2-218-7667 E-mail: charnwit_k@yahoo.com
}

The work is funded by The $90^{\text {th }}$ Anniversary of Chulalongkorn University Fund (2008) (Ratchadaphiseksomphot Endowment Fund)

\begin{abstract}
According to the problems of cadmium contamination in soil at Mae Sot district, Tak province, this study attempts to examine the shift of active microbial population according to cadmium concentration variation around the zinc mine by using RT-PCR of the bacterial 16S rRNA gene and DGGE profiles analysis. The results showed that the amount of total cadmium and zinc was in the range from 1.1 to $34.95 \mathrm{mg} / \mathrm{kg}$ soil and from 27.05 to $1998 \mathrm{mg} / \mathrm{kg}$ soil, respectively. At the highest cadmium concentration $(34.95 \mathrm{mg} / \mathrm{kg}$ soil) the highest diversity index was obtained. Cluster analysis from DGGE pattern indicated two different clusters in the samples. The two soil samples with the cadmium amounts were similar to the EU Maximum Permissible level $(3.0 \mathrm{mg} / \mathrm{kg}$ soil) belonged to one cluster and the leftovers belonged to another. The Pearson correlation between the diversity index and cadmium values was significantly positive.
\end{abstract}

Keywords: Cadmium, Zinc mine, 16S rRNA, DGGE, Microbial population

\section{Introduction}

Cadmium (Cd) usually occurs in association with zinc ore ( $\mathrm{Zn})$ and accumulated in water and soil as by-product of $\mathrm{Zn}$ mining. Cd was absorbed into human body through respiration and eating. It would be accumulated into liver and kidney. Above body's threshold, Cd causes nausea, abdominal pain, kidney dysfunction and osteomalacia (Simmons et al., 2005).

The first case study was observed in 1950 at Jinzu river basin, Toyama prefecture, Japan. As a result of Kamioka Zn mine released liquid wastes into the river that normally used within the community and paddy field irrigation causing Itai-itai disease and greater than hundred lives were lost. Thereafter, they found $\mathrm{Cd}$ in contaminated soil around the river bank at $4.85 \mathrm{mg} / \mathrm{kg}$ soil or around 14 times of unaffected soil $(0.34 \mathrm{mg} / \mathrm{kg}$ soil) (ICETT, 1998).

In Thailand, the biggest $\mathrm{Zn}$ deposit situates in Mae Sot district, Tak province and the estimated mine production capacity is 50000 metric tons (Padaeng Industry Public Co., Ltd., 2008). Mining actions for example drilling, several explosions, material transfer, mine tailings disposal and drainage may cause the $\mathrm{Cd}$ distribution throughout the area, as mentioned in the research by Soil Analysis Division, Land Development Department, Thailand. The average Cd level in the sediment of cinder stacks was $228.5 \mathrm{mg} / \mathrm{kg}$ soil (Tunmanee and Thongmarg, 2007).

High Cd concentration was reported as the negative factor for soil microorganism metabolism (Renella et al., 2005). Therefore, the microbial community changing would be unavoidable. On the other point of view, changing of microbial community could be the indicator for Cd contamination in soil. 
Formerly, the estimation of soil bacteria are culture-dependent methods which many biases from culturing media and laboratory conditions are always found. Less than $10 \%$ of the total microbial population can grow under these artificial status (Torsvik et al., 1998). Therefore, the culture-independent approaches are widely used in the present to eliminate these limitations.

In this study, the impact of $\mathrm{Cd}$ contamination on the shift of the active portions of soil bacterial diversity around $\mathrm{Zn}$ mining area were examined through 16S rRNA RT-PCR and denaturing gradient gel electrophoresis (DGGE) that show functioning soil bacteria genetic fingerprints (Muyzer, 1999).

\section{Materials and Methods}

\subsection{Sampling sites}

Soil samples were collected from 4 different creeks around Zn mine, located in Mae Sot district of Tak province, which are Huai Mae Tao Ngae Sai, Huai Mae Tao, Huai Mae Ku and Huai Nong Khiao (Figure 1).

\subsection{Soil sampling}

The eight collecting points were specified in the Royal Thai Survey Department topographical paper map scale 1:50 000 . For each soil sampling site, three $10 \mathrm{~cm}$ depth cores were taken, tightly sealed in plastic bag and kept at $-20^{\circ} \mathrm{C}$ until the experiment began.

\subsubsection{Sample preparation}

Three soil cores from each sampling point were mixed and air dried. To removed plant debris and gravel dried soil was sieved through a $2 \mathrm{~mm}$ wire mesh.

\subsubsection{Soil characteristics determination}

Soil $\mathrm{pH}$ was investigated on 1:1 soil:water solution. Soil texture was estimated using Hydrometer. Organic matter (OM) was determined according to Walkley and Black method. The cation exchange capacity (CEC) was measured by ammonium saturation method (Department of Land Development, 2004). The total $\mathrm{Cd}$ and $\mathrm{Zn}$ were extracted with boiling aqua regia and detected by an inductively coupled plasma-optical emission spectrometry (ICP-OES), Optima 2001 DV (Perkin Elmer, USA) (Amacher, 1996).

\subsection{RNA extraction}

RNA from soil samples were extracted based on Griffiths et al.'s method (2004) and treated with RQ1 RNase-free DNase (Promega) as the manufacturer's instructions.

\subsection{Reverse transcription PCR (RT-PCR)}

The amplification of RNA templates was performed by a $B c a$ Best $^{\mathrm{TM}}$ RNA PCR Kit Ver.1.1 (Takara, Japan) according to the manufacturer's instructions (Hoshino and Matsumoto, 2007). The cDNA was amplified further with the primer pair: GC-341F and 907R (Muyzer et al., 2004) by using a Takara Ex Taq and performed in a GeneQ thermal cycler TC-24/H (Bioer Technology, China). The touch-down temperature cycling condition was used, lowering the annealing temperature $1^{\circ} \mathrm{C}$ every cycle from $64^{\circ} \mathrm{C}$ to $55^{\circ} \mathrm{C}$ and then run further 10 cycles at $55^{\circ} \mathrm{C}$. The RT-PCR was verified for the absence of DNA contamination by subjected the same reaction without Reverse transcriptase.

The product were analyzed after electrophoresis $(100 \mathrm{~V}, 40 \mathrm{~min})$ on $1.5 \%$ agarose gel then stained with ethidium bromide $(\mathrm{EtBr})$.

\subsection{DGGE determination}

The mix PCR product from each soil sample $(30 \mu \mathrm{l})$ was loaded to $6 \%$ polyacrylamide in $1 \mathrm{x}$ TAE buffer at $60^{\circ} \mathrm{C}$ then run at $100 \mathrm{~V}$ for $18 \mathrm{~h}$ with gradient between $35 \%$ to $70 \%$ using the DCode system (Bio-Rad, USA). Gel was stained with EtBr and photographed by GelDoc XR (Bio-Rad, USA).

\subsection{Microbial pattern analysis}

DGGE image was analyzed with Quantity One version 4.6.1 software (Bio-Rad, USA), the total number of bands within a gel lane was determined as species richness $(R)$ (Ampe et al., 2000) and the Shannon-Weaver index $(H)$ of soil bacterial diversity was calculated based on the band intensity and number of bands as follows:

$H=-\Sigma\left(\mathrm{P}_{\mathrm{i}}\right)\left(\log \mathrm{P}_{\mathrm{i}}\right)$

where $P_{i}=n_{i} / N, n_{i}$ is the peak intensity of a band and $N$ is the sum of peak intensities within each lane (Briones et al., 2008).

Correlation between the Shannon index and other parameters was performed by program $\mathrm{R}$ for Windows version R-2.9.0 (R Development Core Team, 2009). 


\section{Results and Discussions}

\subsection{Sampling points}

The 4 creeks (Huai, in Thai) of sampling sites are dendritic pattern and flow from east to west into the Moei river. Huai Mae Tao Ngae Sai places in the north-eastern highland of Zn mining while Huai Mae Tao situates on north-western part, flows through the mine and discharges to alluvial plain at Ban Mae Tao Mai. Huai Nong Khiao, a creek in the south-western highland of $\mathrm{Zn}$ mine, does not related to mining since it is on the other side of the hill. On the other hand, Huai Mae Ku locates along the south boundary of the mine and flows through Ban Mae Ku Nuea.

\subsection{Soil properties}

As presented in Table 1, soil $\mathrm{pH}$ were almost neutral while the OM varied from $4.03 \%$ to $7.98 \%$. Therefore, they are categorized as high organic level soil (Department of Land Development, 2004). Every sample was coarse (sandy loam) except MT2 which was medium-texture soil (loam). For CEC, three of them (MT4, MT5 and R2) can be classified into rather low exchange rating and the rest five of them were moderate.

From the analysis results, the soils in this area are rich top soil. The neutral $\mathrm{pH}$ and high organic matter make them as a suitable site for agriculture.

\subsection{Concentrations of total $\mathrm{Cd}$ and $\mathrm{Zn}$}

Total $\mathrm{Cd}$ and $\mathrm{Zn}$ contents in eight soil samples are shown in Table 1. Focus on Cd, the sample that was collected from Huai Mae Tao Ngae Sai (MT1), the creek which not pass through the mining area, had Cd quantity near the EU Maximum Permissible (MP) level (3.0 mg/kg soil) (Simmons et al., 2005) while the sample at Huai Nong Khiao (R1) was found $\mathrm{Cd}$ level only $1.1 \mathrm{mg} / \mathrm{kg}$ soil. Huai Mae $\mathrm{Ku}$ had high Cd concentrations especially the R2 site which is a dike for the community irrigation. It might suggest that the water retention in the area causes the Cd accumulation. At the downstream of Huai Mae Ku (R3) found Cd amount 5 times lower than the upstream (R2), implied that Cd in soils are higher than water and water is an intermediate which carries Cd to accumulate at the dike.

Huai Mae Tao which flows through the $\mathrm{Zn}$ mine, found the lower level of $\mathrm{Cd}$ in the upriver (MT2) and increased at the downstream (MT3-MT5). The accumulation range of Cd between MT2 and MT3 is estimated as 2 times whereas the expansion rate at MT3 to MT5 is $13 \%$ per site. From these data, it might assume that the water usage within the community lead to the $\mathrm{Cd}$ accumulation in soils into the hazardous level.

\subsection{Soil microbial profiles}

The DGGE patterns generated from the universal primers for general bacteria (GC-341F and 907R) were exposed the active bacterial composition in Cd-contaminated soil samples (Figure 2).

The low Cd soil ( $\leq 3.05 \mathrm{mg} / \mathrm{kg}$ soil) which is MT1 and R1 samples gave banding patterns 8 bands while the highest (R2) showed 18 bands with distinctive intensity were observed, indicating the presence of different kinds of active bacteria.

It is obviously to notice that the intensity of bands in sample with $3.05 \mathrm{mg} / \mathrm{kg}$ soil (MT1) is greater than the lowest Cd soil (R1). Band (1) was found when Cd amounts are $3.05-7.55 \mathrm{mg} / \mathrm{kg}$ soil (MT1 and R3) in range and faded away in higher $\mathrm{Cd}$ concentrations while band (2), the 2 closest bands, appeared deeply sharp only in the highest Cd quantity sample (R2). This might believed that band (1) should be a good indicator of soil that has the Cd exceed the standard level whereas band (2) should be an indicator when soil carries much higher amount.

The similarity of each lane were analyzed by using UPGAMA clustering method and illustrated into a dendrogram (Figure 3). From the dendrogram, there were two major clusters showed about 30\% similarity which are MT1 and R1. Cd levels of both sites were similar to the EU standard, while another group had much higher Cd amounts.

According to the $H$ index (Table 3), the sample R2 had the highest microbial diversity. Furthermore, when considered the correlation of these results and the soil properties with Pearson correlation ( $r$ ) (Table 4) it was found that only Cd values of soil samples had rather strong positive coefficient $(r=0.768)$ at the 0.05 level where there are no correlation occurred with other variables. These may be concluded that only $\mathrm{Cd}$ concentrations had the direct effect on the active soil bacterial communities.

When consider in the Cd levels above 7.55 or at 8.45 to $34.95 \mathrm{mg} / \mathrm{kg}$ soil in range (MT2-MT5, and R2) found that the relationship between $\mathrm{Cd}$ quantities and diversity index is clearly corresponded as shown in Figure 4. It might suggested that the active bacterial diversity is higher when the $\mathrm{Cd}$ amounts are greater than or approximate to $9 \mathrm{mg} / \mathrm{kg}$ soil as similar to the evidence that stated by Wang et al. (2007). In case of the lower levels, there could be other factors influenced to the bacterial functions especially nutrients and conditions of each sample apart from Cd concentrations (Wang et al., 2007).

The results from this study suggest that Cd contamination impact on the active soil bacteria provide the information in the real field situation and further research is needed to discover the role of these functioning bacteria and explain their influence within the contaminated environment. 


\section{References}

Amacher, M. C. (1996). Methods of soil analysis: nickel, cadmium and lead. In D. L. Sparks. (Ed.), Methods of soil analysis. Part3: Chemical methods. Wisconsin: American Society of Agronomy and Soil Science Society of America. pp. 739-768.

Ampe, F., \& Miambi, E. (2000). Cluster analysis, richness and biodiversity indexed derived from denaturing gradient gel electrophoresis fingerprints of bacterial communities demonstrate that traditional maize fermentations are driven by the transformation process. International Journal of Food Microbiology, 60, 91-97.

Briones, A. M., Shililu, J., Githure, J., Novak, R., \& Raskin, L. (2008). Thorsellia anophelis is the dominant bacterium in a Kenyan population of adult Anopheles gambiae mosquitoes. The ISME Journal, 2(1), 74-82.

Department of Land Development. (2004). Manual for analysis of soil, water, fertilizer, plant, soil amendment and standard quality control of merchandise. Bangkok: WJ Properties, (Chapter 2-3).

Griffiths, R. I., Manefield, M., Whiteley, A. S., \& Bailey, M. J. (2004). DNA and RNA extraction from soil. In G. A. Kowalchuk, F. J. de Bruijin, I. M. Head, A. D. Akkermans, \& J. D. van Elsas. (Eds.), Molecular microbial ecology manual. ( $2^{\text {nd }}$ ed.). Netherlands: Kluwer Academic Publishers. pp. 1.11/149-158.

Hoshino, Y. T., \& Matsumoto, N. (2007). DNA- versus RNA-based denaturing gradient gel electrophoresis profiles of a bacterial community during replenishment after soil fumigation. Soil Biology \& Biochemistry, 39(2), 434-444.

International Center for Environmental Technology Transfer (ICETT). (1998). Preventative measures against water pollution Jinzu river, Toyama prefecture. [Online] Available: http://www.icett.or.jp/lpca_jp.nsf/a21a0d8b94740fbd492567ca000d5879?OpenView (March 23, 2007)

Muyzer, G. (1999). DGGE/TGGE a method for identifying genes from natural ecosystems. Current Opinion in Microbiology, 2(3), 317-322.

Muyzer, G., Brinkhoff, T., Nübel, U., Santegoeds, C., Schäfer, H., \& Wawer, C. (2004). Denaturing gradient gel electrophoresis (DGGE) in microbial ecology. In G. A. Kowalchuk, F. J. de Bruijin, I. M. Head, A. D. Akkermans, \& J. D. van Elsas. (Eds.), Molecular microbial ecology manual. $\left(2^{\text {nd }}\right.$ ed.). Netherlands: Kluwer Academic Publishers. pp. 3.13/743-770.

Padaeng Industry Public Company Limited. (2008). Annual report 2008. [Online] Available: http://www.padaeng.com/pdf/Annual/2008_AnnaulReport.pdf (June 11, 2009).

R Development Core Team. (2009). A language and environment for statistical computing. R Foundation for Statistical Computing. [Online] Available: http://www.R-project.org (April 22, 2009)

Renella, G., Mench, M., Landi, L., \& Nannipieri, P. (2005). Microbial diversity and hydrolase synthesis in long-term Cd- contaminated soils. Soil Biology \& Biochemistry, 37(1), 133-139.

Simmons, R. W., Pongsakul, P., Saiyasitpanich, D., \& Klinphoklap, S. (2005). Elevated levels of cadmium and zinc in paddy soils and elevated levels of cadmium in rice grain downstream of zinc mineralized area in Thailand: Implications for public health. Environmental Geochemistry \& Health, 27(5-6), 501-511.

Torsvik, V., Daae, F. L., Sandaa, R. A., \& Øvreås, L. (1998). Novel techniques for analysing microbial diversity in natural and perturbed environments. Journal of Biotechnology, 64(1), 53-62.

Tunmanee, N., \& Thongmarg, J. (1994), Contamination of cadmium in soils in some area of Thailand. [Online] Available: http://www.ldd.go.th/pldweb/tech/RISabst/analyst37c.htm (April 15, 2007).

Wang, Y., Shi, J., Wang, H., Lin, Q., Chen, X., \& Chen, Y. (2007). The influence of soil heavy metals pollution on soil microbial biomass, enzyme activity, and community composition near a copper smelter. Ecotoxicology \& Environmental Safety, 67(1), 75-81.

Wang, J., Lu, Y., \& Shen, G. (2007). Combined effects of cadmium and butachlor on soil enzyme activities and microbial community structure. Environmental Geology, 51, 1221-1228. 
Table 1. Soil samples characteristics with total $\mathrm{Cd}$ and $\mathrm{Zn}$ amounts

\begin{tabular}{|c|c|c|c|c|c|c|c|}
\hline Creek $^{1}$ & Sample & pH & OM (\%) & Texture $^{2}$ & $\begin{array}{c}\text { CEC } \\
\text { (cmol/kg) }\end{array}$ & $\begin{array}{c}\text { Cd } \\
\text { (mg/kg soil) }\end{array}$ & $\begin{array}{c}\text { Zn } \\
\text { (mg/kg soil) }\end{array}$ \\
\hline A & MT1 & 6.3 & 4.89 & SL & 10.10 & 3.05 & 97.45 \\
B & MT2 & 6.5 & 7.98 & L & 13.41 & 8.45 & 19.85 \\
B & MT3 & 6.5 & 5.81 & SL & 12.91 & 18.80 & 1998 \\
B & MT4 & 6.8 & 5.97 & SL & 8.60 & 22.50 & 954 \\
B & MT5 & 6.8 & 4.03 & SL & 6.99 & 1.10 & 1163 \\
C & R1 & 6.7 & 6.32 & SL & 14.71 & 34.95 & 27.05 \\
D & R2 & 6.7 & 4.31 & SL & 7.39 & 14.57 & 789 \\
D & R3 & 6.8 & 5.39 & SL & 14.57 & 316.05 \\
\hline
\end{tabular}

$\dagger^{1}$ A: Huai Mae Tao Ngae Sai; B: Huai Mae Tao; C: Huai Nong Khiao; D: Huai Mae Ku.

${ }^{2}$ SL: Sandy Loam; L: Loam.

Table 2. Biodiversity index $(H)$ calculated from the DGGE pattern and species richness $(R)$

\begin{tabular}{|c|c|c|}
\hline Sample & $\boldsymbol{H}$ & $\boldsymbol{R}$ \\
\hline MT1 & 0.68 & 8 \\
MT2 & 0.60 & 5 \\
MT3 & 0.93 & 14 \\
MT4 & 0.78 & 8 \\
MT5 & 0.87 & 9 \\
R1 & 0.64 & 8 \\
R2 & 1.18 & 18 \\
R3 & 0.99 & 16 \\
\hline
\end{tabular}

Table 3. Pearson correlation coefficients between microbial diversity and soil parameters $(P<0.05)$

\begin{tabular}{|c|c|}
\hline Parameters & $\begin{array}{c}\text { Correlation with } \\
\text { diversity index }\end{array}$ \\
\hline Cd & $0.768^{*}$ \\
Zn & 0.471 \\
pH & 0.403 \\
OM & -0.646 \\
CEC & -0.377 \\
\hline
\end{tabular}






$\dagger \mathrm{o}=$ villages in Mae Sot district

$$
\text { * = sampling points }
$$

$x=\mathrm{Zn}$ mine $=$ roads - - _ - = creeks

Figure 1. Map of soil sampling points

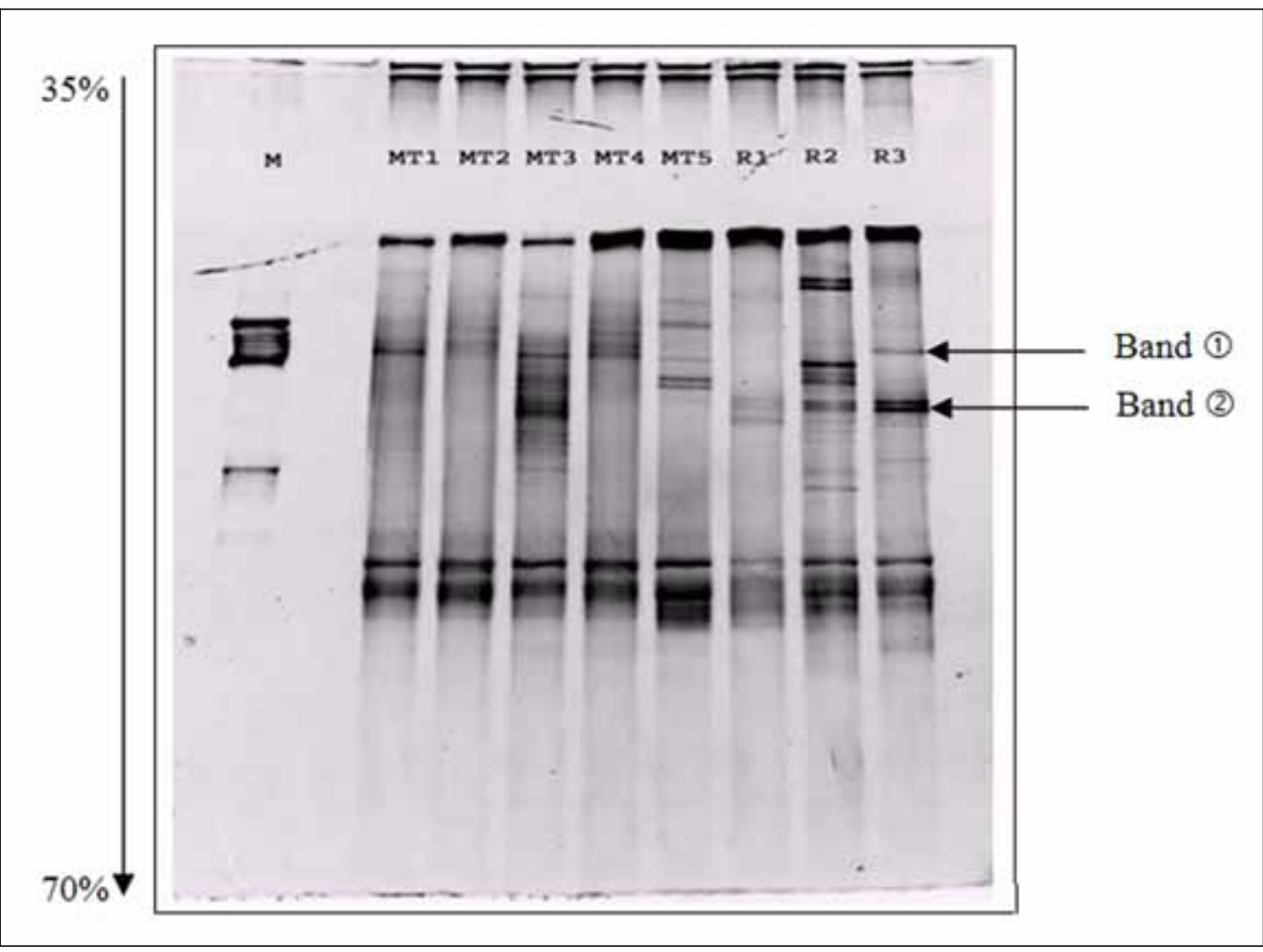

Figure 2. DGGE profiles of functioning bacterial communities based on 16S rRNA from eight Cd-polluted soil samples 


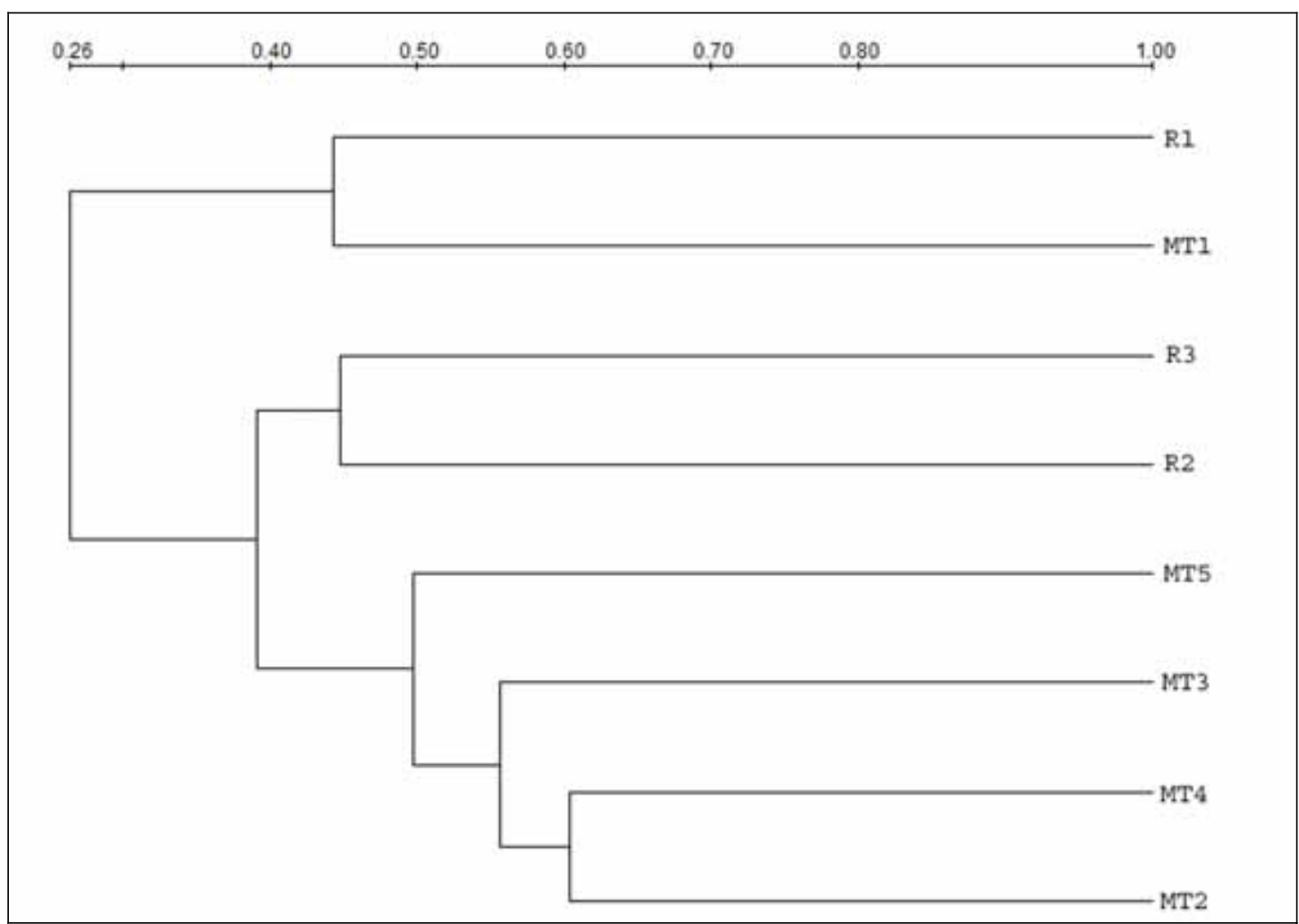

Figure 3. Similarity of the DGGE bacterial communities in soil samples MT1-R3

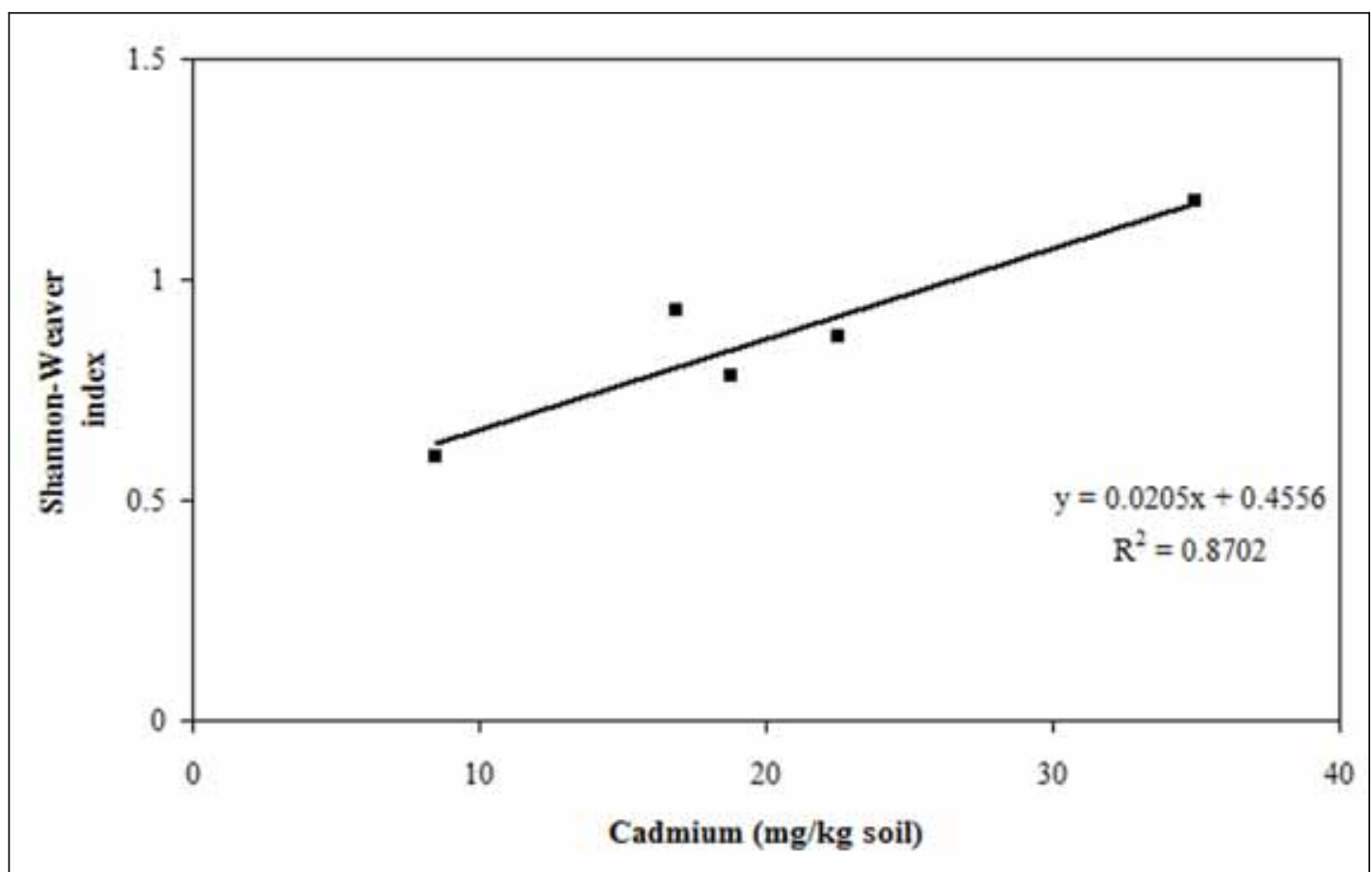

Figure 4. Trend of the active bacterial diversity index at Cd levels 8.45 to $34.95 \mathrm{mg} / \mathrm{kg}$ soil 